\title{
The Hopeless University: Intellectual Work at the End of the End of History
}

\section{Richard Hall ${ }^{1}$ iD}

Published online: 14 July 2020

(C) Springer Nature Switzerland AG 2020

\begin{abstract}
The University is being explicitly restructured for the production, circulation and accumulation of value, materialised in the form of rents and surpluses on operating activities. The pace of restructuring is affected by the interplay between financial crisis and Covid-19, through which the public value of the University is continually questioned. In this conjuncture of crises that affect the body of the institution and the bodies of its labourers, the desires of Capital trump human needs. The structural adjustment of sectoral and institutional structures as forms, cultures as pathologies, and activities as methodologies enacts scarring. However, the visibility of scars has led to a reawakening of politics inside and beyond the University. The idea that History had ended because there is no alternative to capitalism or its political horizon, is in question. Instead, the political content of the University has reasserted itself at the end of The End of History. In this article, the idea that the University at The End of History has become a hopeless space, unable both to fulfil the desires of those who labour within it for a good life and to contribute solutions to socio-economic and socioenvironmental ruptures, is developed dialectically. This enables us to consider the potential for reimagining intellectual work as a movement of sensuous human activity in the world, rather than being commodified for value.
\end{abstract}

Keywords Crisis $\cdot$ Hopelessness $\cdot$ Humane values $\cdot$ Intellectual work $\cdot$ University $\cdot$ Value

\section{Introduction: the Value of the University}

Constant revolutionizing of production, uninterrupted disturbance of all social conditions, everlasting uncertainty and agitation distinguish the bourgeois epoch from all earlier ones. All fixed, fast frozen relations, with their train of ancient and venerable prejudices and opinions, are swept away, all new-formed ones become

Richard Hall

rhall1@dmu.ac.uk

1 Education Division, De Montfort University, Leicester LE1 9BH, UK 
antiquated before they can ossify. All that is solid melts into air, all that is holy is profaned, and [humans are] at last compelled to face with sober senses [their] real condition of life and [their] relations with [their] kind. (Marx and Engels 1848/ 2002: 13)

The University has been forced into a constant rear-guard action, having to defend its governance, regulation and funding against relentless scrutiny. This ongoing analysis is an attempt to shape a particular terrain upon which the idea or symbolism of the University can be contested, and this symbolism often bears little resemblance to how the University is experienced by those who labour inside it. These experiences are concrete and active, but they are also the result of, and immanent to, individual and collective interpretations, hopes, myths, histories, anxieties and more. These are projected onto how we imagine the University is governed, regulated and funded, and the relationship between this imaginary and the symbolism of the University has a formative power in defining the subjectivity of University workers (Lacan 1994).

Subjectivity is shaped by University structures that reveal its shifting forms, cultures that appear as pathologies, and activities recalibrated as methodologies. These forms, pathologies and methodologies are then hidden from those University workers, because they are mediated rather than emerging through direct association between individuals. Thus, the market, the desire for academic commodities as private property that can be exchanged and the divisions of privileged, academic labour appear to dominate. These mediations act as cover for refusing and alienating the humanity of intellectual work, because the meaning of the University is generated through a desire for value, which is visualised as a surplus or profit. This value is bourgeois rather than human and is predicated upon an idea of University work that can be validated through individual, subject-based and institutional performance management.

Value is central to any understanding of the idea of the University and how it is contested by those immediately immersed in it, like academics, professional services' staff, students and their families, and those who orbit it, like professional associations, philanthrocapitalists, venture capital, policymakers, educational technology vendors, credit ratings agencies and lenders in bond markets. This latter group form a fluid, interconnected, transnational activist network seeking to reengineer the University for the purpose of extracting surpluses, in the form of rents, debt repayments, new commodities as knowledge exchange, or forms of human capital (Szadkowski 2016). Reengineering erupts from the systemic compulsion of the totality of capitalist social relations for an expansion in the universe of value, through what is experienced as constant revolutionising. This generates an 'epoch-making mode of exploitation, which in the course of its historical development revolutionises the entire economic structure of society by its organisation of the labour process and its gigantic extension of technique' (Marx 1857/1993: 120).

The economic structure of society, materialised through relations and forces of production, is perpetually in motion under capitalism. Expansion demands the systemic alienation and exploitation of those who work and whom are contracted either to generate surplus-value over-and-above the value of their wage or to reproduce the infrastructures for value production. The alternative is deflation, stagnation or depression. Inside higher education (HE), expansion is linked to extraction, exploitation and expropriation, which impact both the relations and forces of production (Fraser 2016). 
This is experienced across a wide corporeal and psychological terrain through the following: increased workloads; demands for knowledge exchange, research impact and commercialisation; internationalisation strategies aimed at opening up new markets; casualisation and precarious employment; intersectional inequalities in promotion and tenure; attacks on pensions and wages; demands for more innovation in (online) teaching; the sanctity of data and algorithmic control in setting strategies (Morrish and Sauntson 2019).

The drive behind constant revolutionising is for universities to increase the value of academic commodities, by reducing the quantity of intellectual labour that is socially necessary for their production and their circulation in the market. This is grounded in reducing the quantity of time. This might be the time for knowledge transfer, or to turnaround marking, or to develop and deliver an accelerated degree. There is a given, global, average level of productivity, and being able to undercut this average gives an institution competitive edge, crucial in the struggle for student fees, research funding and league table position. Therefore, differential technical composition of specific forms of intellectual labour is brought into stark relief in the market. As such, the quantitative value of a specific commodity or activity is determined by abstract (homogeneous) human labour measured by time, rather than social purpose (heterogeneous).

This is reinforced ideologically by the desire for data that promise enriched monitoring or tracking of performance, alongside behavioural changes (Williamson 2020). Data again reinforce how the symbolism of the University is predicated upon the imaginaries of a network or ecosystem of external actors, who work to shape its forms, pathologies and methodologies. Flows of data enable new quantifications of University work, underpinned by a machinery of global production that disassembles existing flows of labour, finance and technology and reassembles them for profit or rent. The fusion of new technologies and technocratic modes of organising work creates new forces and relations of production, which coalesce as the Platform University. Moreover, fusing technologies, flows of data and quantification, behavioural science and algorithmic governance reinforces white, colonial and patriarchal hegemonic norms (Boyd 2017).

In the Platform University, algorithmic control points to the movement of Right (Hegel 1942), or the search for transhistorical truth and certainty. It promises to finesse a controlled ecosystem for collecting rent, enabling and distributing human capital and exchanging and transferring commodities. The platform enables the University to impose flexploitation through the creation of micro-activities or micro-commodities in relation to the production of curriculum content, research outputs, assessments and so on (Morgan and Wood 2017). This makes academic work precarious and entrepreneurial and brings the particular nature of that work into relation with algorithmic control as a moving, capitalist Reason, which can be optimised for value (Huws 2014; Srnicek 2017).

In these ways, Capital as a totalising system is revealed as an inhuman power, driving intensification and proletarianisation in the struggle for both the accumulation of value and increased rates of profit (Marx 1844/1974, 1894/1991). Capital is an ongoing crisis for those forced to labour, in order to exist, and the capitalist University increasingly exemplifies that crisis. Moreover, crises of capital, in the form of underconsumption (e.g. of courses), overproduction (e.g. of $\mathrm{PhD}$ graduates) or falling 
rate of profit (e.g. weak net cash inflow for investment), also shape the symbolism of the University. This is an institution seemingly shaped only in relation to crisis.

\section{The Value of the University-in-Crisis}

The latest financial crisis to impact capitalism, triggered in 2007, has been used to justify further commodification of life under austerity politics. The University been really subsumed inside the evidenced-based imaginary of the market (Hall and Bowles 2016). On the one hand, it is treated as an input, or a means of production, into a wider economic system that has come to dominate life. On the other hand, it is treated as a material representation of a chronically and historically failing system, to be infiltrated by consultancies working in the name of agility, innovation, productivity and value-formoney (Bevins, Bryant, Krishnan, and Law 2020). Infiltration is accelerated by the systemic inability to catalyse new forms of accumulation, coupled with both the need to generate surpluses of time, labour, value and money, and the demand to find outlets for a mass of inactive, financial surpluses. These generate:

- A flood of new credit, for instance, student and institutional debt that reinforce a financialised, political ideology

- A focus upon infrastructure projects, based upon brand management and a desire for productivity by increasing the organic composition of capital (i.e. increasing the amount of fixed capital that an individual unit of labour can put to work)

- Hoarding of surpluses for investment in infrastructure, rather than on academic labour

- A policy focus upon productivity and the development of human capital, grounded in entrepreneurship and commercialisation; database control of staff and student performance

- The ongoing separation of institutional governance and sector regulation, from the production of knowledge

The working conditions of University labourers are reduced to a common sense of economic survival, with political decisions about the institution outsourced to bureaucrats. Yet, the validity of this common sense has been challenged by Covid-19 as a generalised threat to the human body. Economistic common sense has been thrown into asymmetrical relationship with the corporeal need for human survival, as competing institutions and their regulators seek to mitigate or adapt to the impacts of the pandemic. This coronavirus crisis has been overlain on top of the secular crisis of capitalism, revealed as a long depression (Roberts 2018), and has thrown the desire for value into stark relation with humane values.

Thus, attempts at mitigation or adaptation have included calls for bailouts in the UK (Universities UK 2020), or for a virtual, national and federated University of New Zealand (Newstalk ZB 2020). These have focused upon maintaining the content of business-as-usual and preserving its institutions, with University workers expected to bear the cost of preservation. Calls for preservation through restructuring, merging or federating have been interpreted as academia's shock doctrine (Kornbluh 2020). This reflects the material and historical reality that crises of Capital demand sacrifices, in 
order to release idle or unproductive skills, knowledge, capabilities and infrastructures from sectors, businesses and individuals deemed less useful or with lower productive potential (Marx 1894/1991). Adaptations to, or mitigations of, the specifics of coronavirus are colonised and mediated by Capital's constant revolutionising. In spite of the shattered confidence and faith in the structures of everyday social interaction, the pandemic illustrates our difficulty in escaping the symbolic power of capitalist social relations (de Sousa Santos 2020).

It becomes difficult to consider University work for another world, precisely because the interaction between societies and nature, ecology and the world is governed by a metabolism, or form of social metabolic control, grounded in ongoing extraction, exploitation and expropriation (Clark and Bellamy Foster 2010; Bhattachariyya 2018). In their inability to reimagine own labour, coupled with anxious exhaustion about the pandemic situation, University workers are reduced to tactical struggles, like the invasion of work into homelife and its impact on caring responsibilities or costs. As capital uses the crisis to colonise the home and social reproduction further, the University is revealed inside monopolies of power that delegitimise self-care. Colonising leaves scars through the violence of structural adjustment.

\section{Structural Adjustment and Hysteresis}

Structural adjustment erupts from the dynamics of capitalist social production grounded in the treadmill of competition between businesses like universities, inside sectors like $\mathrm{HE}$ that are brought into interdependence with other sectors of the economy. Interconnections emerge through innovations that revolutionise the relations or forces of production, and yet these innovations also amplify competition, which in turn changes the organic composition of those universities and sectors. In response to Covid-19 forecasts of reduced fees from international, domestic and postgraduate students, limited research funding and low net cash inflow, institutions are planning redundancies; capitalising upon distance or online provision; refusing to furlough staff on fixedterm or part-time, hourly paid contracts; asking staff to take pay cuts; and intensifying algorithmic management and communication systems (London Economics 2020; Workers Inquiry Network 2020).

As the University life cycle, driven by the circuits of capital, is ruptured by the uncertainties in the life cycle of the coronavirus, injustices are intensified. In the desire for business-as-usual, it is impossible for capitalist time to slow or stop, in order for humans to understand their emerging material (corporeal and psychological) and historical (temporal) relationship to the virus. The abstract world of capital appears to have more power than the concrete world of the virus. Hence, responses are predicated upon the balance of risk between physical and economic death, measured against the possibility of a second wave of the pandemic and new lockdown measures (Oxford Economics 2020). Yet those very responses are also affected by hysteresis, or the permanent structural, corporeal or psychological scarring caused by an event. So, the generalised transmission of Covid-19 into the human population creates effects that manifest themselves as persistent problems in established systems of social reproduction. Problems like economic growth or output cannot rebound back to a pre-crisis trend line, because that would require accelerated and impossible levels of production. 
Thus, the GDP available for services or investment is permanently lost. Growth may return to a long-term rate of expansion, but without rebound back to the pre-crisis trend, there are permanent scarring and losses (Cerra and Saxena 2018).

Hysteresis makes a nonsense of ideas of business-as-usual or a return to normality for universities, as cash flow, operating income, turnover, surpluses and output are each reduced and cannot be recovered. However, it also challenges liberal cries to preserve or sustain the sector. Overlapping crises reveal the privileged symbolism and ideation of the Public University, which faces the social necessity of reproducing value, through productivity and competition. Thus, calls for bailouts and assistance for students, like the Coronavirus Aid, Relief, and Economic Security (CARES) Act in the USA or Canada's Bill C-15 including Emergency Student Benefit, or bailouts for institutions, come with conditions set by finance capital. Across economies and universities, the pandemic tests eligibility for support, based upon instantiating new relations and forces of production, like mergers, federations, homeworking or hybrid forms of delivery. This is the context for the Public University, which is further scarred by a loss of academic capacity, for instance, in relation to established research and public engagement around climate forcing or social inclusion.

In responding to hysteresis, competition drives institutions at the core of HE sectors, represented by research-intensive institutions that are export-driven, prestigious and international, to accumulate or compensate for lost income at the expense of institutions at the periphery already over-leveraged against specific student or debt markets. Those over-leveraged institutions then work to replace more expensive university labourers with those who are cheaper, and to deploy more technology (Hershbein and Kahn 2018). As established sectoral and institutional quantitative thresholds are breached, in terms of operational activity, teaching, research and public engagement, qualitative changes are imposed ideologically. For University workers, the result is either further anxiety in an age of heightened uncertainty and risk (Morrish and Priaulx 2020) or cynicism about the academic project (Allen 2020).

Under the rule of Covid-19, one option would have been democratic planning and governments bearing the risk of uncertainty for institutions, with the speed of transition to new ways of working underwritten by cheap credit, central management of infrastructural investment, or bailouts. Instead, the market and private investment remain pre-eminent, thereby skewing socially needed investment towards that which is behavioural, incentivised and economic (Bossie and Mason 2020). Market coordination is maintained with institutions owning uncertainty and risk, in relation, first, to student recruitment and markets, operating activities and research and, second, the development of new forms of organisational development and entrepreneurial activity. This is the structurally adjusted, symbolic common sense of public HE.

For University workers, this common sense shapes a pathology of powerlessness, reinforced by calls for self-sacrifice that are integral to the reproduction of bourgeois society (Marx 1852). Thus, academic staff are expected to plan for both fully online and hybrid future delivery, whilst also delivering the same quality of education, and institutions performance manages the risk for the maintenance of quality and value-formoney. These projected risks regulate the metabolic relationship between public and University, through the struggle over value and business continuity. As global labour markets, including that for academic labour-power, are forcibly adjusted under the 
pandemic, a new, structurally adjusted normal will scar workers anew unless ruptured by the struggle for an alternative.

\section{The University at the End of History}

The immanence of viral and financial pandemics has thrown the imaginaries upon which we base our understandings of the world into confusion. Coronavirus inflects economic populism, protectionism and the rise of the alt-right, the politics of austerity, climate forcing and metabolic rifts, and creates a new historical and material terrain of struggle. However, the symbolism of capitalism denies any horizon of possibility beyond its continued accumulation and organisation of social life. In this view, History has ended because capitalism and its institutions are natural and transhistorical, and in this End of History, our imaginations cannot process alternatives (Fukayama 1992). Yet, reinforcing crises have called this into question, such that at the end of The End of History (Aufhebunga Bunga 2019), there is a renewed tension over whether it is easier to imagine the end of the world (and of our humane values) than it is the end of the capitalist University (and its drive for economic value) (Jameson 1994, following Franklin 1979)?

The University is emblematic of the collapse in the symbolic power of humans to reimagine the world. Even whilst they enrich the general intellect of society, or our collective wealth in skills, knowledge, capacities and capabilities (Marx 1857/1993), University workers have not been able to imagine how such enrichment might operate beyond mediations like the market, which seem to form an impregnable realm or kingdom (de Sousa Santos 2020). Instead, those workers have complied with the acceleration of a society defined technocratically and in economistic terms, at great cost to those who labour inside it and who are left to compete for scarce privilege, status and power, though institutional and subject-based structures.

At The End of History, these structures create textures or forms of value, whose content and commodities are created through, first, cultures revealed as pathologies of overwork, self-harm and self-sacrifice (Hall and Bowles 2016) and, second, activities of teaching, learning, research and administration that describe methodologies for control and performance management (Birmingham Autonomous University 2017). Inside these forms, the pathological and methodological content of the institution is internalised by the University worker and her ego-identity, thereby diminishing the potential for mutuality. Differential levels of proletarianisation in the conditions of labour, shaped by competition over status, militate against the creation of common ground between University workers or struggles for humane work. These include:

- Academic labourers at the University of Sunderland in the UK, fighting cuts to humanities and social sciences courses in 2020

- Graduate students at the University of California, Santa Cruz, taking part in wildcat strikes since 2019 to demand living wages

- The 2012 student protests in Québec against debt and the imposition of Bill 78 limiting dissent

- Struggles in 2019 at the University of Juba in South Sudan against tuition fee hikes that threatened the right to education 
- The history of protest at Jawaharlal Nehru University in Delhi, including the 2016 sedition row, and 2019 struggles over accommodation fees and India's Citizenship Amendment Act

- Struggles for decolonisation, like Rhodes Must Fall at the universities of Cape Town and Oxford, alongside the educational activities of Black Lives Matter

- Movements against sexual violence on campuses, including the work of the 1752 Group based in the UK

In spite of these struggles, the University is still painted as a liberal institution that simply needs reform, rather than transformation or abolition (Meyerhoff 2019). This liberal position maintains the reified symbolic power of the University and cannot trace the links between institutions under capitalism, which enable the reproduction of intersectional and liminal injustices, in the name of value (Motta 2018). Reification is grounded in values and modes of performance represented by white, colonial and patriarchy, and these are the grounds upon which the institution, its disciplines and individuals are judged and performance-managed (Amsler and Motta 2017). This enables the separation of the political economy and humanist potential of intellectual work, separated out in the form academic labour. Whilst this divorces the University from its potential contribution to social transformation, at The End of History, policy in the bourgeois institution obsesses over productivity, efficiency and value-for-money (Ansell 2020).

Elsewhere, Critical University Studies has identified how, in governance, regulation and funding, HE is not working, and to look for solutions that recover or redeem the idea of the University (Connell 2019). Analyses have applied a range of historical models to the sector (Brandist 2016); focused upon particular fractions of academic labour, like professors (Evans 2018); highlighted enclosures through discourses of policy and language (Morrish and Sauntson 2019); and centred upon the acceleration of the Platform University (Hoofd 2017). Alternatives include recovering 'the public university' (Holmwood 2011); building educational co-operatives (Woodin and Shaw 2019); recovering reified norms of academic freedom (Furedi 2017); refining the idea of the University in relation to the market (Frank, Gower, and Naef 2019); or considering the social and ecological futures of the University and its publics (Facer 2019). The University is an anchor point in any social re-imagination, but it needs to be recentred away from dominant, neoliberal discourse.

These counter-narratives tend to describe organising principles that desire a better capitalist University, framed by hope, love, care, solidarity and so on. They form a terrain of outrage, but they tend to lack a deeper, categorical analysis of either the forces or relations of production that discipline and give texture and meaning to the University. There is limited possibility for a critique that situates University work against its basis in alienated labour (Hall 2018), through which the 'vampire' of Capital exists because it feeds upon living labour (Marx 1867/2004). Moreover, they risk preserving hegemonic imaginaries that are not mindful of intersectional and indigenous experiences and ways of knowing the world. This limits our collective engagement with radical imaginaries (Andreotti 2016; Elwood, Andreotti, and Stein 2019), subaltern struggles (Moten and Harney 2013) or structural disadvantage (Darder 2018), and instead reinforces how the University has become a failed or impossible redeemer (Allen 2017). 
At The End of History, the flow of capitalist time reproduces a global, exploitative, cognitive caste system that is reinforced by the legitimacy of universities in the Global North, their disciplinary separations and their claims to knowledge-as-truth. These claims are systemic and algorithmic, centre around particular determinations of effectiveness and efficiency and able to be fine-tuned to reinforce a trajectory of timeless growth. In part, this is how the University's forms, pathologies and methodologies amplify the compulsion for algorithmic modes of control. It is how universities have been able to use abundant living labour to move online during the pandemic and thereby create new platform ecosystems at low short-term cost.

Here, there are questions around whether the University is too fragile to cope with the future impacts of financial crisis and pandemic and needs accelerated and agile reengineering. The World Bank report on 'Global Waves of Debt' (Kose, Nagle, Ohnsorge, and Sugawara 2019) and International Monetary Fund report 'Debt Is Not Free' (Badia, Medas, Gupta, and Xiang 2020) highlight the vulnerability of sectors and economies that are over-leveraged, and in which profitability and investment are assumed under low interest rates and precarious or surplus employment. A separate World Bank Group report (2020: 7) on the pandemic shock and policy responses highlights the need to generalise 'innovations and emergency processes, [so that] systems can adapt and scale up the more effective solutions.' Regardless of economic or psychological scarring, at The End of History, turning 'recovery into real growth' becomes yet another opportunity for capital to impose its shock doctrine of structural adjustment.

Here, University disciplines are reduced to highlighting issues around inequality and associated policy responses (Piketty 2020) or analysing the psychological impacts of economic instability (Collier 2018). In general, the forms, pathologies and methodologies that reproduce the University are unable to imagine a world beyond capitalist social relations at the end of The End of History. This inability is reinforced by the divorce between the politics and governance of the University and its deterministic, economic symbolism. The fragmentation of work, shaped by a loss of co-operation beyond competition, scarred by precarity and oriented around value rather than humanity, generates hopelessness.

\section{The Reproduction of Hopelessness Inside the University}

Responses to the pandemic have tended to mirror those for climate forcing, although the timescale requires more intensive action. In the scramble to maintain business-asusual and the same form of the institution or its key function as a competing business, sustainability is overlain on top of existing strategies for teaching, research, internationalisation, commercialisation and so on. Here, institutions project responsibility onto the individual for managing her resilience or mindfulness, or the value of her programmes of study and research, and then use the crisis to make cuts and re-engineer. As institutions and sectors use the crisis to accelerate commodification, there is a risk that a new hopeless or depressive position subsumes autonomy and withers hope (Iorio and Tanabe 2019), or living concepts like hygge (Larsen 2019), inside the University.

The University worker's position is rendered more hopeless where she can see induced behaviours are incongruent with her inner being. However, they are enforced through sanctions, surveillance or performance management that are toxic, and subject 
to constant revolutionising alongside the coercive necessity of alienated labour (Marx 1844/1974). This is the logic of the University, in which all potentially sensuous or meaningful activity is objectified as powerlessness and self-loss. In the reproduction of the capitalist University, this catalyses hopelessness in two senses. The first lies in the inability of the University to address crises other than in relation to value, through the imposition of authoritarian forms of management, pathological cultures of growth or business-as-usual, and methodological activities that fixate on commodity exchange. It has therefore become a useless use-value, in the sense that its social worth and its feasibility are defined by flows of capital, with the creation of a liveable environment for all secondary. The hopeless University has become devoid of useful content.

The second sense lies in an understanding of how capital structures and disciplines the labour of love inside the University, negating its humane possibilities, and as a result breeds despair, depression and melancholy as a space beyond anxiety. Any hopes that universities might be places for the creation of new forms of freedom or social wealth are marginalised by the imposition of precarious existences inside anxiety machines that catalyse overwork and ill-being (Hall and Bowles 2016). Increasingly, those who work inside universities have either to become self-exploiting or self-harming or to deploy enough cognitive dissonance to overcome the lack of authentic hope that another world might be possible. Dissonance is harder to maintain as academic work becomes more explicitly remade for-value and determined in the market.

Inside institutions that reproduce structures/forms, cultures/pathologies and activities/methodologies that are withering, a starting point is sitting with hopelessness as a trigger for authentic grief and mourning. Rather than uncritical hope, defensive lamentation or yearning for an idealised, historical and public place, this process of grieving demands that labourers understand how hopelessness is reproduced inside the University. Discussions have opened up about the reinforcement of objectification and the denial of subjectivity, such that University workers become habituated to inhumanity. This is reflected in the recent analyses of the Zombie University (Smyth 2017); the Automatic University (Williamson 2020); the University in ruins (Readings 1996); the Psychotic University (Sievers 2008); Whackademia (Hil 2012); the University as a ruined laboratory (Dyer-Witheford 2011), or a branch office of conglomerates (Derrida 2001); terminal subjectivities in HE (Allen 2017); the need to hospice the University (Andreotti, Stein, Ahenakew, and Hunt 2015); and fugitive existences in the University (Moten and Harney 2013).

The hopelessness theory of depression is useful here in framing these metaphors through the relationship between depressive symptoms and the loss of agency, alongside the amplification of individual vulnerability inside environments that are negative imaginaries (Schneider, Gruman, and Coutts 2012). Inside institutions like universities which govern themselves overtly and covertly through endemic intensification, selfharm, shaming, performance management and intersectional injustices (Ahmed 2017; Gill 2009), it is possible to analyse the development of vulnerability using Chabot's (2018) work on global burnout. He focuses upon the impact of overwork, alongside mental and physical exhaustion, in relation to values-driven, service work. This is especially the case in sectors that are performance-managed around excellence and whose metabolism is defined as a struggle over scarce resources, status and privilege. Chabot (2018: 12) states that burnout 'replaces the richness of a healthy relationship between individuals and their work with an immense void of meaninglessness'. 
Here hopelessness has a layered complexity linked to an inability to consider future positives, such that a negative miasma or contagion generates vulnerability (MacLeod, Rose, and Williams 1993). Inside highly competitive environments, vulnerability also tends to shape a deeper relationship between defeat, entrapment and depression (Tarsafi, Kalantarkousheh, and Lester 2015). Here, persistent and seemingly inevitable negative events become 'occasion setters' that can trigger hopelessness (Abramson, Metalsky, and Alloy 1989). These might include negative student assessments, being overlooked for promotion or tenure, daily micro-aggressions, an unmanageable workload, limited research grant success and so on. Forms, pathologies and methodologies shape environments in which negative outcomes come to be expected (Abramson et al. 1989; Abramson et al. 2000). These have been described in a range of quitlit (literature about quitting the Academy) and sick-lit (literature about illness in the Academy).

Hopelessness, powerlessness and vulnerability are amplified through histories of patriarchy, colonialism, exclusion and intersectional injustice, which engender cultural and political depression (Fitz-Henry 2017; Xiao et al. 2014). It is important to recognise the differential ability to exist without hope or to withstand structural injustices that limit individual agency in the face of hopelessness. Intersectional injustices are reproduced inside forms, by pathologies and methodologies that question the legitimacy and value of certain bodies (Ahmed 2017). Sitting with these injustices potentially uncovers ways of knowing the Self in relation to the structural inequalities and textures of the institution, and thereby to understand issues of trust, agency and voice. This is central in enabling individuals, working in a divided, competitive environment, and who are struggling with a range of negative events, to work against seeing themselves as useless. This is central in understanding tactics for survival pending revolution, including cynicism, stoicism, apathy, refusal, becoming fugitive, exodus or organising. These describe the boundaries of personal agency in hopeless ecosystems.

Thus, whilst pessimism might more accurately describe the Weltschmerz felt by many staff and students (Abramson et al. 1989), hopelessness becomes a useful heuristic for analysing the forms, pathologies and methodologies designed to exploit labour inside the University. A systemic treatment of hopelessness places the individual, her environment and her society into asymmetrical relationship, rather than focusing upon the individual's learned helplessness or psychological deficits. This takes the particular evidence of increased occupational health referrals, reports of mental distress, and suicides not as individual failings, but instead as moments for reconceptualising those experiences at the level of the University (Morrish 2019).

The collective, academic capacity to do this work of critique was questioned half a century ago by Le Baron (1971: 567): 'I could exhort my fellow academics to work within academia towards a new consciousness, transcending habits of egoism, competition, and possessing, but I am all too conscious of Marx's biting attacks on such "idealistic" and "utopian" methods.' More recently, Szadkowski (2016: 49-50) argued that 'the hierarchically organized community of scholars is a rather non-antagonistic force to capital'. As the scholarly community of the University demonstrates its hopelessness, subaltern University workers might come to hospice the organisation as it passes away (Andreotti et al. 2015). This may be the case for those struggling with the inability of intellectual work inside the University to overcome helplessness in the face of environmental crises. Here, the ability to sit with hopelessness, or to exist without hope, enables an acceptance of being in the world, rather than the University's 
insistence that we labour to control it. Understanding the ways in which the University seeks to impose control, and the ways in which hopelessness ruptures the Self inside the organisation, requires a dialectical mode of analysis.

\section{Dialectics of Hopelessness}

The hopeless University emerges dialectically though three moments (Dunayevskaya 2002; Lenin 1981). First is an engagement with thinking that brings universal concepts into relation with particular experiences, in order to question existing structures, cultures and practices and thereby generate new universals. This is a movement of thinking that situates the symbolism of the institution against the range of ways in which it is imagined in practice, in order to move towards a concrete understanding of its reality. It also places those existing structures of the institution, alongside its cultures and practices, in relation to the totality of capitalist social relations. Second is elaborating the relationship between quantitative and qualitative change. The experience of life inside the University is subject to constant, measurement and the attempt to validate conceptual clarity about the world through evidence or data that are a quantity of experience. At particular moments, quantity describes qualitative change, for instance, in new conceptualisations or discourses of the student-as-consumer, the platform University, the quantified self or the need for decolonisation.

There are also societal relations immanent to these qualitative changes, and which challenge the relation of data to discourses, and the reproduction of power and privilege. Thus, Hegel (2010: 179-80) noted how 'number stands between the senses and thought', helping to develop 'the category of the internally self-external that defines the sensuous'. Here, the concrete world experienced by individuals is brought into relation with symbolic, external contexts through mediations like the market. This imminence between quantitative tipping points and qualitative change shifts cultures and perceptions and offers a moment of conceptual or psychological negation. This is the third dialectical moment, the law of the negation of the negation. Here, there exists the ongoing movement of society, beyond everyday activities like assessment and laboratory research, or that which mediates social progress, like the power of the division of labour. Thus, calls for state funding for Higher Education under Covid-19 negate the sanctity of private property and the consumption of education-based services. However, this negation then reveals the contradictions between the private and public values of a degree, which leads to further questioning of the idea of the University.

Crucially, Hegel (2018) raises the idea of an external, sensuous consciousness, which Marx (2004) later inverts, in terms of activity in the world being practical and human-sensuous. This is a reminder that humans make the world and that there is potential for generating meaning that is not achieved through the objectification of education for the development of human capital. This dialectical unfolding of particular, concrete experiences of the world, in relation to universal conceptions that normalise or stabilise thinking, is overlain by individual and structural factors in reproducing the totality of capitalism. Thus, the University is implicated in our social relations, and our social relations are implicated in the University, at one and the same time. This immanence impacts levels of control, anxiety and hopelessness as the structures/forms that shape University work are compelled by the value-form; the 
cultures/pathologies of the University exploit our relationship to nature, the environment and each other; and our activities/methodologies reproduce alienating labour processes.

Social existence inside the University gives texture to a set of fluid identities, in particular for academics, whose work is centred around a perceived identity between thought and being. Identities are fluid because internal conceptions and external forms, pathologies and methodologies are in dialectical relation. As a result, subjectivity is mediated by the relationship between the academic-as-subject and the objects of her consciousness (including workloads, learning environments, technologies, peers). These are determined materially and historically by particular forms of social existence. At the transition between The End of History and the end of The End of History, a struggle over subjectivity erupts for University workers who are told that uncertainty can be controlled through algorithmic control and self-sacrifice, but for whom the development of certainty is immanent to their consciousness of that environment as hopelessly alienating.

Struggle demands a many-sided analysis of social forces, political actions, relations and forces of production, in order to understand what is possible. The requirement is to abstract concrete qualities from different objects or experiences, like inequitable workloads or analyses of attainment gaps, in order to generate new abstractions or universal conceptions. This brings individual characteristics into direct relation with the totality of social existence, and potentially offers new modes of negation, or social transformation. This is not idealism; rather, it is a materialism that questions capitalism's transhistorical claims to bourgeois equality (Marx 1875/1970). Thus, it becomes possible to bring diverse imaginaries of hopeless and powerless experiences in the University into relation with its symbolism as a mode of organising capitalist social relations. In response, it is possible to imagine the negation of, for instance, the commercialisation of research as private property; the status and privilege of the academic division of labour; and intellectual competition rooted in commodity exchange.

It is then possible to imagine the abolition of the hopeless University and the legitimacy of its forms, pathologies and methodologies for intellectual work. Abolition aims at sublating or assimilating and overcoming barriers to human living, in order that an alternative world becomes possible. This negative, dialectical mode of thinking is important because the Spirit (or Reason) of capitalist social relations that controls life is abstract and symbolic, as well as being imagined or experienced concretely (through precarity, overwork, ill-health and so on). By thinking of the University dialectically, a negative possibility emerges from the diversity of experiences that pushes beyond the historical and material symbolism of the University-as-is. Instead, the potential for qualitative change is situated as transformational (Adorno 1966).

A movement of dialectical thinking reveals subjectivity as a constant movement of becoming, in which categories of life are brought into comparison and contradiction. Here there is a struggle over two different conceptions of life. First is life calibrated around capitalist institutions that impose a totalising movement of value and which measure difference and diversity against hegemonic norms. This is the Reason of capitalism. Second is life emerging from negative dialectics (Adorno 1966), raising the possibility for alternative conceptions that cannot be synthesised from particular identities and their non-identities. This recognises that subjectivity is formed from 
ontological and epistemological imaginaries grounded in difference. It is the refusal to abstract this difference around dominant modes of quantification that forms humane connections, or the potential for unity-through-difference.

Such heterogeneous thought offers boundaries that determine a horizon of hope. This is not the idealism of Hegel, focused upon the unfolding of the Idea, or the Absolute Spirit beyond humanity; rather, it is Marx's conception of the study of History as the primary science. Hope erupts at the end of The End of History. It is a historical and material dynamic, which is a movement of sensuous human activity in the world, and 'the consistent consciousness of nonidentity' (Adorno 1966: 5). Moreover, it is a process of ongoing reflection that continually critiques reality, by bringing different imaginaries of the world into relation to show the unity of universal difference. Struggle is crucial in this process of critique and is predicated upon the potential for rupturing and transcending the imposition of labour as the mode of social organisation. In analysing the struggle for authentic intellectual work at the end of The End of History, this is the starting point for transcending the symbolism of the hopeless University.

\section{The University at the End of the End of History}

The duality of financial and viral pandemics has exposed the fraud at the heart of narratives of meaningful intellectual work at The End of History. It exposes the fraud at the heart of the structures, cultures and activities of universities in the North Atlantic, whose pathological and methodological forms reproduce space-time inextricably forvalue. Capitalism as the means of social organisation continues to be ruptured by intersectional, temporal and geographical injustices that erupt from points of labour and points where labour touches society. A range of indigenous resistances, struggles grounded in race, gender, disability and class, emergent revolts against toxic ecological policies and climate forcing and resistance to economic and political populism, form a movement that places the institutions of Capital in stark opposition to humane values. Through struggle, the political economics of Capital's war on Labour are revealed, although in many instances they require critique.

For University workers, such critique centres the institutional inability to respond meaningfully to this re-emergence of History, beyond unilaterally declaring businessas-usual in the face of Covid-19, or noting a climate emergency whilst remaining implicated in the consumption of fossil fuels. At the end of The End of History, when the abstracted power of capital has revealed its pollution of systems of life and living, the hopeless University demonstrates the inferiority in its soul. It is dominated by strategies for public engagement, internationalisation, teaching and learning, research and sustainable development, which collapse the horizon of possibility and are limited to algorithmic solutions to insoluble, structural and systemic positions. The hopeless University is a flag bearer for a collective life that is becoming more efficiently unsustainable.

Mutuality and voice point beyond hopelessness. As Adorno (1966: 17-18) noted, ' $[\mathrm{t}]$ he need to let suffering speak is a condition of all truth. For suffering is objectivity that weighs upon the subject'. For Bloch (1986), engaging with the internalisation of anxiety and its projection into the world as fear is a means to recover a more authentic sense of what the Self might be in the world. An authentic moment of freedom is 
learning that a better capitalist University, like a capitalism that works for everyone, is impossible because the structures that reproduce the world for-value militate against a liveable life. Instead, hope emerges in care for ourselves against the institutions that have brutalised us. It emerges in a reconnection of the idea of human-as-intellectual, with the human-as-psychological and the human-in-nature, rather than the human divorced from herself as a worker and exploiter of the natural world.

The hopelessness of capitalism, amplified by the University and its focus upon knowledge transfer, spillover, human capital, impact, excellence and so on, is refused where people remember and uncover their own capacities. The hopeless University hides our latent or undeveloped abilities from us, or it strips our developed skills, knowledge and capacities from us, in the name of value. Refusal emerges from the ability of University labourers to conceptualise themselves as a force for themselves, rather than focusing upon their privilege and status (with a limited consciousness as a class in itself). A moment of possibility lies organisationally, in seeing similarities, connections and solidarities across the range of academic and professional services staff, and students, who labour inside the University, and making connections to struggles at the level of society.

Refusal emerges where people understand the potential of and in their own mass intellectuality (Hall and Winn 2017). This offers a different route away from hopelessness, through constant reflection on what has been incorporated or lost, and thereby emerges renewed through mourning. This is Bloch's (1986) idea that a life that sits authentically with hopelessness moves towards hope precisely because it acknowledges what is possible from inside the current situation. This is not a melancholic or despairing hope for a return to an idealised University. As History returns, the hegemonic symbolism of institutions that further estrangement from active knowing, doing, being and becoming must be refused and their ontologies and epistemologies negated (Holloway 2016). Instead, particular imaginings of universal concepts of human existence inside capitalism are a moment of resistance and refusal. Understanding and recognising those particular experiences point towards unity-through-difference as a new mode of organising social life.

Thus, in refusing the idea of the hopeless University, indigenous, feminist, decolonial, queer, disabled, intersectional conceptions, counter-cartographies and narratives offer guides (Mbembe 2019). These counterpoints frame intellectual work in relation to the body, soul, psyche, collectivity and nature, through the past, present and future. This moves us from functional analyses of our near-term extinction (Bendell 2018), to a discussion of what it means to live well in this moment, and the potential to discuss alternative, plural horizons of possibility (Elwood et al. 2019). As Cleaver (2017: 290) argues 'We are no longer talking about replacing one world with another, but one world with many.' Here, socially useful intellectual work at the end of The End of History uncovers processes of knowing, doing and being, rather than sanctifying knowledge that can be commodified. In respecting the unity of our difference, as humans rather than academics, professional services' staff or students, we can turn our attention to 'the only scientific question that remains to us...: how the fuck do we get out of this mess?' (Holloway 2010: 919).

For University workers, this begins from the question: how do we know the University? In the act of knowing, empathy emerges, rather than imaginaries that are aggrieved, disappointed, helpless or hopeless. The symbolism of the hopeless 
University is a limit to any such transformation, because it is structured around forms, pathologies and methodologies for the commodification and mediation of intellectual work. With no categorical analysis of this symbolism, labourers idealise hope, and yet hope is no plan. Instead, a dialectical process of transcendence is needed, which highlights the one-sidedness of knowledge, institutions and disciplines as limiting factors in determining understanding (Dunayevskaya 2002).

This is a moment of courage, which recognises the need to know authentically and plurally the diseased and pathological context for suffering inside the University. This recognises alienation, ill-being and ill-health as symptomatic of structural processes experienced differentially. Suffering is absolutely relative, and in this emerges a potential horizon of possibility. A next step asks whether it is possible to forgive the University, and take responsibility for how we feel about it, alongside our own projections and internalisations. Instead of being dominated by the University, projecting our own hopes and fears onto it, as well as internalising its modes of privilege and performance, this might begin the process of focusing upon intellectual work as it is integrated inside ourselves as complete humans capable of sensuous, practical activity in common.

\section{Compliance with Ethical Standards}

Conflict of Interest The authors declare that they have no conflict of interest.

\section{References}

Abramson, L. Y., Alloy, L. B., Hogan, M. E., Whitehouse, W. G., Gibb, B. E., Hankin, B. L., \& Cornette, M. M. (2000). The hopelessness theory of suicidality. In T. E. Joiner \& M. D. Rudd (Eds.), Suicide science: Expanding boundaries (pp. 17-32). Boston, MA: Kluwer Academic Publishing.

Abramson, L. Y., Metalsky, G. I., \& Alloy, L. B. (1989). Hopelessness depression: A theory-based subtype of depression. Psychological Review, 96, 358-372. https://doi.org/10.1037/0033-295X.96.2.358

Adorno, T.W. (1966). Negative dialectics. Trans. E. B. Ashton. New York: Seabury Press.

Ahmed, S. (2017). Living a feminist life. Durham, NC: Duke University Press.

Allen, A. (2017). The cynical educator. Leicester: Mayfly Books.

Allen, A. (2020). Cynicism. Boston, MA: The MIT Press.

Amsler, S., \& Motta, S. (2017). The marketised university and the politics of motherhood. Gender and Education, 31, 82-99. https://doi.org/10.1080/09540253.2017.1296116.

Andreotti, V. (2016). Research and pedagogical notes: The educational challenges of imagining the world differently. Canadian Journal of Development Studies, 37(1), 101-112. https://doi.org/10.1080 /02255189.2016.1134456.

Andreotti, V., Stein, S., Ahenakew, C., \& Hunt, D. (2015). Mapping interpretations of decolonization in the context of higher education. Decolonization: Indigeneity, Education \& Society, 4(1), 21-40.

Ansell, K. (2020). Articulating value: creating a compelling narrative. Oxford, UK: Higher Education Policy Institute (HEPI). https://www.hepi.ac.uk/2020/01/27/articulating-value-creating-a-compelling-narrative/. Accessed 12 May 2020.

Aufhebunga Bunga. (2019) Aufhebunga Bunga is creating the global politics podcast at the end of the end of history. https://www.patreon.com/bungacast. Accessed 12 May2020.

Badia, M.M., Medas, P., Gupta, P., \& Xiang, Y. (2020). Debt is not free. IMF Working Paper 20/1. International Monetary Fund. https:/www.imf.org/en/Publications/WP/Issues/2020/01/03/Debt-Is-NotFree-48894. Accessed 12 May 2020.

Birmingham Autonomous University (2017). Six theses in, against and beyond the university. In R. Hall \& J. Winn (Eds.), Mass intellectuality and democratic leadership in higher education (pp. 129-140). London: Bloomsbury Academic. 
Bendell, J. (2018). Deep adaptation: A map for navigating climate tragedy. Institute for Leadership and Sustainability (IFLAS) Occasional Papers, Volume 2. Ambleside, UK: University of Cumbria. http://www.lifeworth.com/deepadaptation.pdf. Accessed 12 May 2020.

Bevins, F., Bryant, J., Krishnan, C., \& Law, J. (2020). Coronavirus: How should US higher education plan for an uncertain future? McKinsey \& Company, 3 April. https://www.mckinsey.com/industries/publicsector/our-insights/coronavirus-how-should-us-higher-education-plan-for-an-uncertain-future. Accessed 12 May 2020.

Bhattachariyya, G. (2018). Rethinking racial capitalism: Questions of reproduction and survival. London: Rowman \& Littlefield.

Bloch, E. (1986). The principle of hope. Oxford: Wiley-Blackwell.

Bossie, A., \& Mason, J.W. (2020). The public role in economic transformation: Lessons from World War II. New York: Roosevelt Institute, 26 March. https://rooseveltinstitute.org/public-role-in-economictransformation-lessons-from-world-war-ii/. Accessed 12 May 2020.

Boyd, D. (2017). The radicalization of utopian dreams. Data \& Society, 20 November. https://points. datasociety.net/the-radicalization-of-utopian-dreams-e1b785a0cb5d. Accessed 12 May 2020.

Brandist, C. (2016). The Soviet System, Neoliberalism and British Universities. Social Science Space, 27 September. https:/www.socialsciencespace.com/2016/09/soviet-system-neoliberalism-britishuniversities/. Accessed 12 May 2020.

Cerra, V., \& Saxena, S.C. (2018). The economic scars of crises and recessions. IMF Blog, 21 March. https://blogs.imf.org/2018/03/21/the-economic-scars-of-crises-and-recessions/. Accessed 1 July 2020.

Chabot, P. (2018). Global burnout. Trans. A. Krefetz. London: Bloomsbury.

Clark, B., \& Bellamy Foster, J. (2010). The dialectic of social and ecological metabolism: Marx, Mészáros, and the absolute limits of capital. Socialism and Democracy, 24(2), 124-138. https://doi.org/10.1080 /08854300.2010.481447.

Cleaver, H. (2017). Rupturing the dialectic: The struggle against work, money, and financialization. Oakland, CA: AK Press.

Collier, P. (2018). The future of capitalism: Facing the new anxieties. London: Allen Lane.

Connell, R. (2019). The good university: What universities actually do and why it's time for a radical change. London: Zed Books.

Darder, A. (2018). Decolonizing interpretive research: subaltern sensibilities and the politics of voice. Qualitative Research Journal, 18(2), 94-104. https://doi.org/10.1108/QRJ-D-17-00056.

de Sousa Santos, B. (2020). The tragic transparency of the virus. Critical Legal Thinking, 6 April. https:/criticallegalthinking.com/2020/04/06/the-tragic-transparency-of-the-virus/. Accessed 1 July 2020.

Derrida, J. (2001). The future of the profession or the unconditional university. Trans. P. Kamuf. In L. Simmons \& H. Worth (Eds.), Derrida Downunder (pp. 233-48). Palmerston North: Dunmore Press.

Dunayevskaya, R. (2002). The power of negativity: Selected writings on the dialectic in Hegel and Marx. Lanham, MA: Lexington Books.

Dyer-Witheford, N. (2011). Digital labour, species-becoming and the global worker. Ephemera: Theory and Politics in Organization, 10(3/4), 484-503 http://www.ephemerajournal.org/contribution/digital-labourspecies-becoming-and-global-worker. Accessed 12 May 2020.

Elwood, J., \& Andreotti, V., with Stein, S. (2019). Towards braiding. https://decolonialfutures. net/towardsbraiding/. Accessed 12 May2020.

Evans, L. (2018). Professors as academic leaders: Expectations, enacted professionalism and evolving roles. London: Bloomsbury.

Facer, K. (2019). Storytelling in troubled times: What is the role of educators in the deep crises of the 21st century. Literacy, 53(1), 3-13. https://doi.org/10.1111/lit.12176.

Fitz-Henry, E. (2017). Grief and the inter-cultural public sphere: "Rights of nature" and the contestation of "global coloniality". Interface: a Journal for and About Social Movements, 9(2), 143-161 http://www. interfacejournal.net/wordpress/wp-content/uploads/2017/12/Interface-9-2-Fitz-Henry.pdf. Accessed 12 May 2020.

Frank, J., Gower, N., \& Naef, M. (2019). English universities in crisis: Markets without competition. Bristol: Bristol University Press.

Franklin, H. B. (1979). What are we to make of J.G. Ballard's apocalypse? http://www.jgballard. $\mathrm{ca} /$ criticism/ballard_apocalypse 1979.html. Accessed 12 May2020.

Fraser, N. (2016). Expropriation and exploitation in racialized capitalisms: A reply to Michael Dawson. Critical History Studies, 3(1), 163-178. https://doi.org/10.1086/685814.

Fukayama, F. (1992). The end of history and the last man. New York: Free Press. 
Furedi, F. (2017). What's happened to the university? A sociological exploration of its infantilisation. London: Routledge.

Gill, R. (2009). Breaking the silence: The hidden injuries of neo-liberal academia. In R. R. Flood \& R. Gill (Eds.), Secrecy and silence in the research process: Feminist reflections (pp. 228-244). London: Routledge.

Hall, R. (2018). The alienated academic: The struggle for autonomy inside the university. London: Palgrave Macmillan.

Hall, R., \& Bowles, K. (2016). Re-engineering higher education: the subsumption of academic labour and the exploitation of anxiety. Workplace: A Journal for Academic Labor, 28, 30-47. http://bit.ly/2dQMx8X. Accessed 12 May 2020.

Hall, R., \& Winn, J. (Eds.). (2017). Mass intellectuality and democratic leadership in higher education. London: Bloomsbury Academic.

Hegel, G.W.F. (1942). Philosophy of right. Edited and translated by T.M. Knox. Wotton-under-Edge: Clarendon Press.

Hegel, G.W.F. (2010). The science of logic. Edited and translated by G. di Giovanni. Cambridge: Cambridge University Press.

Hegel, G.W.F. (2018). The phenomenology of spirit. Edited and translated by T. Pinkard. Cambridge: Cambridge University Press.

Hershbein, B., \& Kahn, L. B. (2018). Do recessions accelerate routine-biased technological change? Evidence from vacancy postings. American Economic Review, 108(7), 1737-1772.

Hil, R. (2012). Whackademia: An insider's account of the troubled university. Sydney: University of New South Wales Press.

Holloway, J. (2010). Crack capitalism. London: Pluto Press.

Holloway, J. (2016). Against and beyond capital: San Francisco lectures. Oakland, CA: PM Press.

Holmwood, J. (Ed.). (2011). A manifesto for the Public University. London: Bloomsbury Academic.

Hoofd, I. (2017). Higher education and technological acceleration: The disintegration of university teaching and research. London: Palgrave Macmillan.

Huws, U. (2014). Labor in the global digital economy: the cybertariat comes of age. New York: Monthly Review Press.

Iorio, J. M., \& Tanabe, C. S. (2019). Higher education and the practice of hope. New York: Springer.

Jameson, F. (1994). The seeds of time. New York: Columbia University Press.

Kornbluh, A. (2020). Academe's coronavirus shock doctrine. The Chronicle of Higher Education, 12 March. https://www.chronicle.com/article/Academe-s-Coronavirus-Shock/248238. Accessed 1 July 2020.

Kose, M.A., Nagle, P., Ohnsorge, F., \& Sugawara, N. (2019). Global waves of debt: causes and consequences. The World Bank. https://www.worldbank.org/en/research/publication/waves-of-debt. Accessed 12 May 2020.

Lacan, J. (1994). The four fundamental concepts of psycho-analysis. London: Penguin.

Larsen, M. A. (2019). Hygge, and higher education: A case study of Denmark. In P. Gibbs \& A. Peterson (Eds.), Higher education and hope (pp. 71-89). London: Palgrave Macmillan.

Le Baron, B. (1971). Marx on human emancipation. Canadian Journal of Political Science, 4(4), 559570. https://doi.org/10.1017/S0008423900030043.

Lenin, V.I. (1981). Philosophical notebooks. In Lenin collected works, 38. Moscow: Progress Press.

London Economics. (2020). Impact of the Covid-19 pandemic on university finances. Report for the University and College Union. http://londoneconomics.co.uk/blog/publication/impact-of-the-Covid-19pandemic-on-university-finances-april-2020/. Accessed 12 May 2020.

MacLeod, A. K., Rose, G. S., \& Williams, J. M. G. (1993). Components of hopelessness about the future in parasuicide. Cognitive Therapy and Research, 17, 441-455. https://doi.org/10.1007/BF01173056.

Marx, K. (1844/1974). Economic and philosophical manuscripts. Moscow: Progress Publishers.

Marx, K. (1852). The Eighteenth Brumaire of Louis Bonaparte. https://www.marxists. org/archive/marx/works/1852/18th-brumaire/ch01.htm. Accessed 12 May 2020.

Marx, K. (1867/2004). Capital, volume 1: A critique of political economy. London: Penguin.

Marx, K. (1875/1970). Critique of the Gotha Programme. In Marx and Engels selected works, 3 (pp. 13-30). Moscow: Progress Publishers.

Marx, K. (1894/1991). Capital, volume 3: A critique of political economy. London: Penguin.

Marx, K., \& Engels, F. (1848/2002). The communist manifesto. London: Penguin.

Marx, K. (1857/1993). Grundrisse: Outline of the critique of political economy. London: Penguin.

Mbembe, A. (2019). Necropolitics. Durham: Duke University Press.

Meyerhoff, E. (2019). Beyond education: Radical studying for another world. Minnesota, MA: University of Minnesota Press. 
Morgan, G., \& Wood, J. (2017). The 'academic career' in the era of flexploitation. In E. Armano, A. Bove, \& A. Murgia (Eds.), Mapping precariousness, labour insecurity and uncertain livelihoods: Subjectivities and resistance (pp. 82-97). London: Routledge.

Morrish, L. (2019). Pressure vessels: The epidemic of poor mental health among higher education staff. Hepi Occasional Paper 20. Oxford, UK: Higher Education Policy Institute (HEPI). https://www.hepi.ac. uk/2019/05/23/pressure-vessels-the-epidemic-of-poor-mental-health-among-higher-education-staff/. Accessed 1 July 2020.

Morrish, L., \& Sauntson, H. (2019). Academic Irregularities: Language and Neoliberalism in Higher Education. London: Routledge.

Morrish, L., \& Priaulx, N. (2020). Pressure Vessels II: An update on mental health among higher education staff in the UK. Hepi Occasional Paper 23. Oxford, UK: Higher Education Policy Institute (HEPI). https://www.hepi.ac.uk/2020/04/30/pressure-vessels-ii-an-update-on-mental-health-amonghigher-education-staff-in-the-uk/. Accessed 1 July 2020.

Moten, F., \& Harney, S. (2013). The undercommons: Fugitive planning \& black study. Brooklyn: Minor Compositions.

Motta, S. (2018). Liminal subjects: Weaving (our) liberation. London: Rowman \& Littlefield International.

Newstalk ZB (2020). University of New Zealand proposed as borders remain closed. 6 May. https://www. newstalkzb.co.nz/on-air/mike-hosking-breakfast/audio/grant-guilford-university-of-new-zealandproposed-as-borders-remain-closed/. Accessed 12 May 2020.

Oxford Economics. (2020). Coronavirus pandemic could cut world GDP by $\$ 1 \mathrm{tn}$. https://www. oxfordeconomics.com/my-oxford/publications/540003. Accessed 12 May 2020.

Piketty, T. (2020). Capital and ideology. Cambridge, MA: Harvard university Press.

Readings, B. (1996). The university in ruins. Cambridge, MA: Harvard University Press.

Roberts, M. (2018). The long depression: How it happened, why it happened, and what happens next. London: Haymarket Books.

Schneider, F. W., Gruman, J. A., \& Coutts, L. M. (Eds.) (2012). Applied social psychology: Understanding and addressing social and practical problems (2nd ed.). Thousand Oaks, CA: Sage Publications.

Sievers, B. (2008). The Psychotic University. Ephemera: Theory and Politics in Organization, 8(3), 238-257 http://www.ephemerajournal.org/contribution/psychotic-university. Accessed 12 May 2020.

Smyth, J. (2017). The toxic university: Zombie leadership, academic rock stars and neoliberal ideology. London: Palgrave Macmillan.

Srnicek, N. (2017). Platform capitalism. Bristol: Polity Press.

Szadkowski, K. (2016). Towards an orthodox Marxian reading of subsumption(s) of academic labour under capital. Workplace: A Journal for Academic Labor, 28, 9-29.

Tarsafi, M., Kalantarkousheh, S. M., \& Lester, D. (2015). The defeat-entrapment theory versus Beck's hopelessness theory of depression and suicidality: A cross-national analysis in Iran and the United States. International Journal of Social Psychiatry, 61(8), 777-780. https://doi.org/10.1177 /0020764015583921.

Universities UK (2020). Achieving stability in the higher education sector following Covid-19. https://universitiesuk.ac.uk/news/Documents/uuk_achieving-stability-higher-education-april-2020.pdf. Accessed 12 May 2020.

Williamson, B. (2020). Datafication and automation in higher education during and after the Covid-19 crisis. code acts in education, 6 May. https://codeactsineducation.wordpress.com/2020/05/06 /datafication-automation-he-covid19-crisis/. Accessed 12 May 2020.

Workers Inquiry Network. (2020). Struggle in a pandemic: a collection of contributions on the COVID-19 crisis. London: Workers Inquiry Network.

Woodin, T., \& Shaw, L. (Eds.). (2019). Learning for a co-operative world: Education, social change and the co-operative college. London: Trentham Books.

World Bank Group Education. (2020) The Covid-19 pandemic: Shocks to education and policy responses. https://t.co/DHn34oFCZL. Accessed 12 May 2020.

Xiao, J., Qiu, Y., He, Y., Cui, L., Auerbach, R. P., \& McWhinnie, C. M. (2014). 'Weakest link' as a cognitive vulnerability within the hopelessness theory of depression in Chinese University students. Stress and Health, 32(1), 20-27. https://doi.org/10.1002/smi.2571. 